Proc. Éstonian Acad. Sci. Geol., 1995, 44, 2, 119-132

\title{
GEOLOGY OF THE ÄNTU GROUP OF LAKES
}

\author{
Leili SAARSE ${ }^{a}$ and Arvi LIIVA ${ }^{b}$
}

a Eesti Teaduste Akadeemia Geoloogia Instituut (Institute of Geology, Estonian Academy of Sciences), Estonia pst. 7, EE-0100 Tallinn, Festi (Estonia)

b Eesti Teaduste Akadeemia Zooloogia ja Botaanika lnstituut (Institute of Zoology and Botany, Estonian Academy of Sciences), Vanemuise 2, EE-2400 Tartu, Eesti (Estonia)

Presented by A. Raukas

Received 28 June 1994, accepted 20 October 1994

Abstract. The highly alkaline basins of the lakes in the Antu group on the Pandivere Upland, Estonia, are filled with lacustrine lime, which has accumulated since the Preboreal. Silt of the Younger Dryas age lies under the lime. Eleven local pollen assemblage zones were distinguished, with pronounced Betula pollen in the Preboreal, Pinus in the Early Boreal, Ulmus-Alnus-Corylus in the Late Boreal, Ulmus in the Early Atlantic, Tilia in the Late Atlantic, and Picea in the Late Subboreal. The role of the anthropogenic indicators during the Neolithic and Bronze Age is weak, since the Iron Age remarkable. The chronology is based on 16 radiocarbon dates from different materials. Some dates are too old due to the hard water effect, but most fit well with the pollen stratigraphy. After the recession of ice from the Pandivere Upland all three lakes belonging to the northern Antu group formed a large lake, which in the Atlantic split into small ones. At the beginning of the Holocene the lake level was high with one considerable lowering between $4100-3200$ years BP.

Key words: Litho-, bio- and chronostratigraphy; vegetation history; radiocarbon dates; lake-level changes.

\section{INTRODUCTION}

The Antu group of lakes is located on the Pandivere Upland $\left(59^{\circ} 08^{\prime} \mathrm{N}\right.$, $26^{\circ} 33^{\prime} \mathrm{E}$ ) in a bedrock depression deepened by karst processes on the outcrop of limestones of the Porkuni regional stage. The lakes are fed by springs. This is why they have alkaline water and a high water transparency. Three lakes, Sinijärv, Vahejärv (Roheline), and Valgjärv, form the northern Antu group of lakes near the Tartu-Rakvere road, between the Pekkeli-Ebavere esker ridge (Fig. 1). L. Sinijärv, $94.6 \mathrm{~m}$ a.s.l., is small, with a surface area of 2.4 ha and maximum depth of $7.3 \mathrm{~m}$. It has an outlet via L. Vahejärv and L. Valgjärv to L. Linaleo and through Nõmme Brook to the Põltsamaa River. The northern, western, and southern shores are bordered by a narrow peaty rim. East of the lake there is the Kärsa mire. The area of L. Vahejärv is only 0.8 ha, its maximum water depth is $3.3 \mathrm{~m}$, the shores are covered with a floating mat and the bottom with lacustrine lime. L. Valgjärv has an area of 1.4 ha and maximum water depth of $8 \mathrm{~m}$. Similar to the other two lakes its shores are paludified and the bottom is covered with lacustrine lime. 


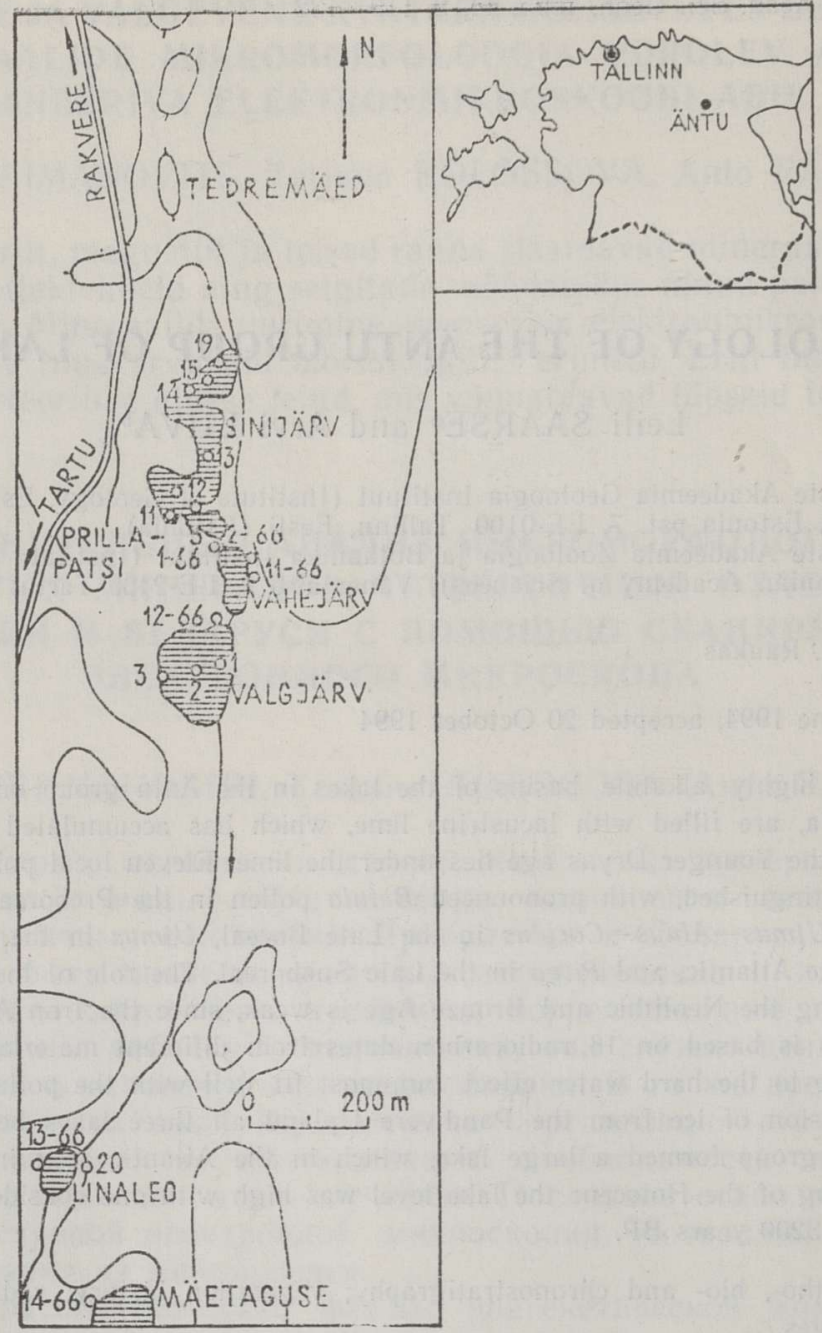

Fig. 1. Location of the Antu group of lakes. o-cores.

The water of the lakes is calcareous, enriched with nutrients, especially with nitrogen during the last ten years (Mäemets \& Saarse, 1995). The water turnover is fast, with mean residence time not exceeding $2-3$ months. It is an interesting object of study due to the highly calcareous deposits, but complicated to date.

\section{STUDIES ON THE SURROUNDINGS OF THE ÄNTU GROUP OF LAKES}

The first studies in the surroundings of the Antu group of lakes were carried out by Männil (1961). The work was continued by Reet Pirrus (unpublished data). The bottom deposits of L. Antu Sinijärv were studied by Saarse in 1966, 1986, and 1987. In 1966 one transect along L. Sinijärv and several cores around lakes Vahejärv, Valgjärv, Linaleo, and Mäetaguse were drilled (Fig. 1, cores 1-66 and 14-66; as the scale is small the cores on L. Sinijärv are not indicated). The water transparency 


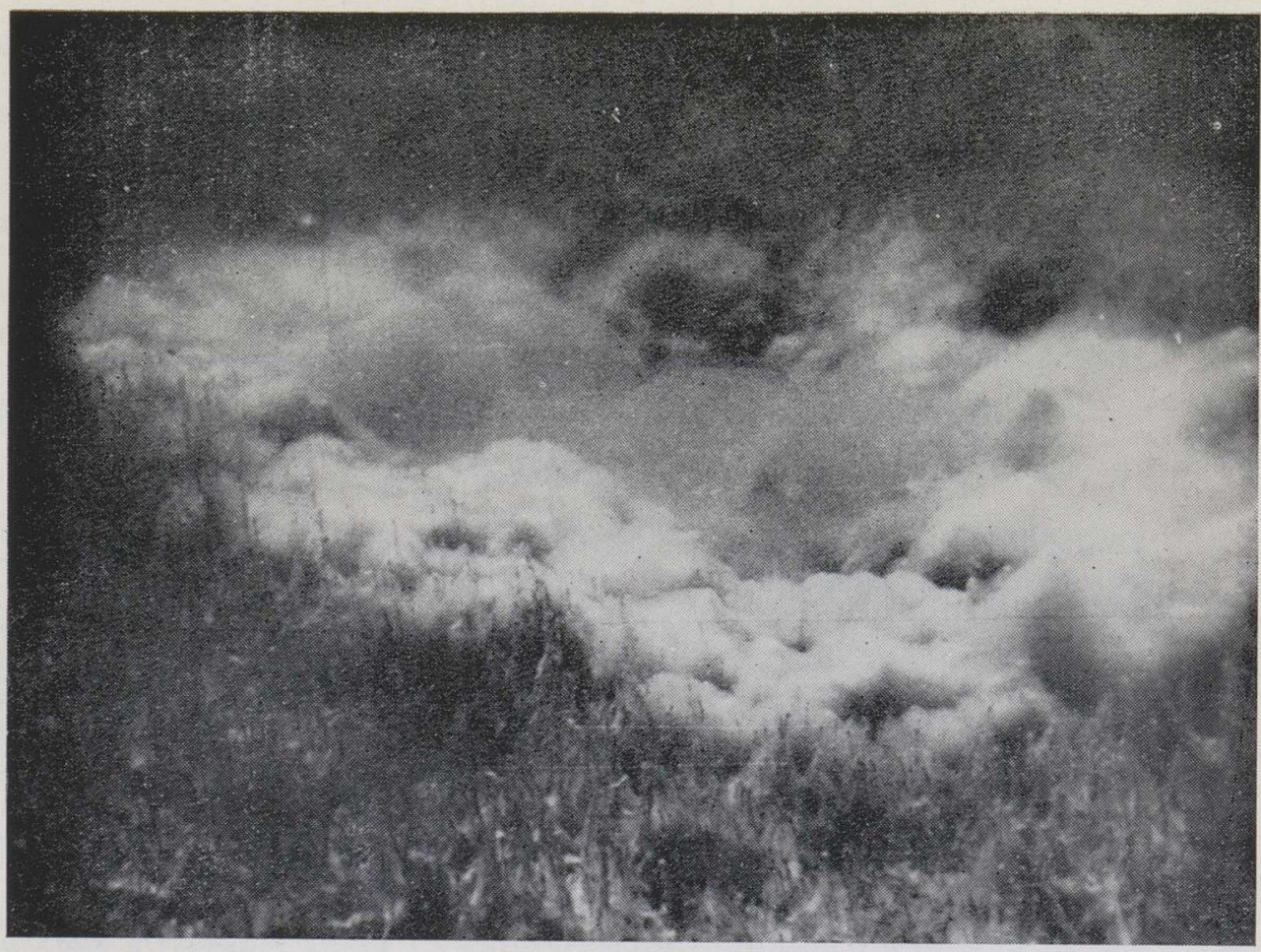

Photo 1. A spring in the bottom of L. Antu Sinijärv. Underwater photo by H. Saarse.

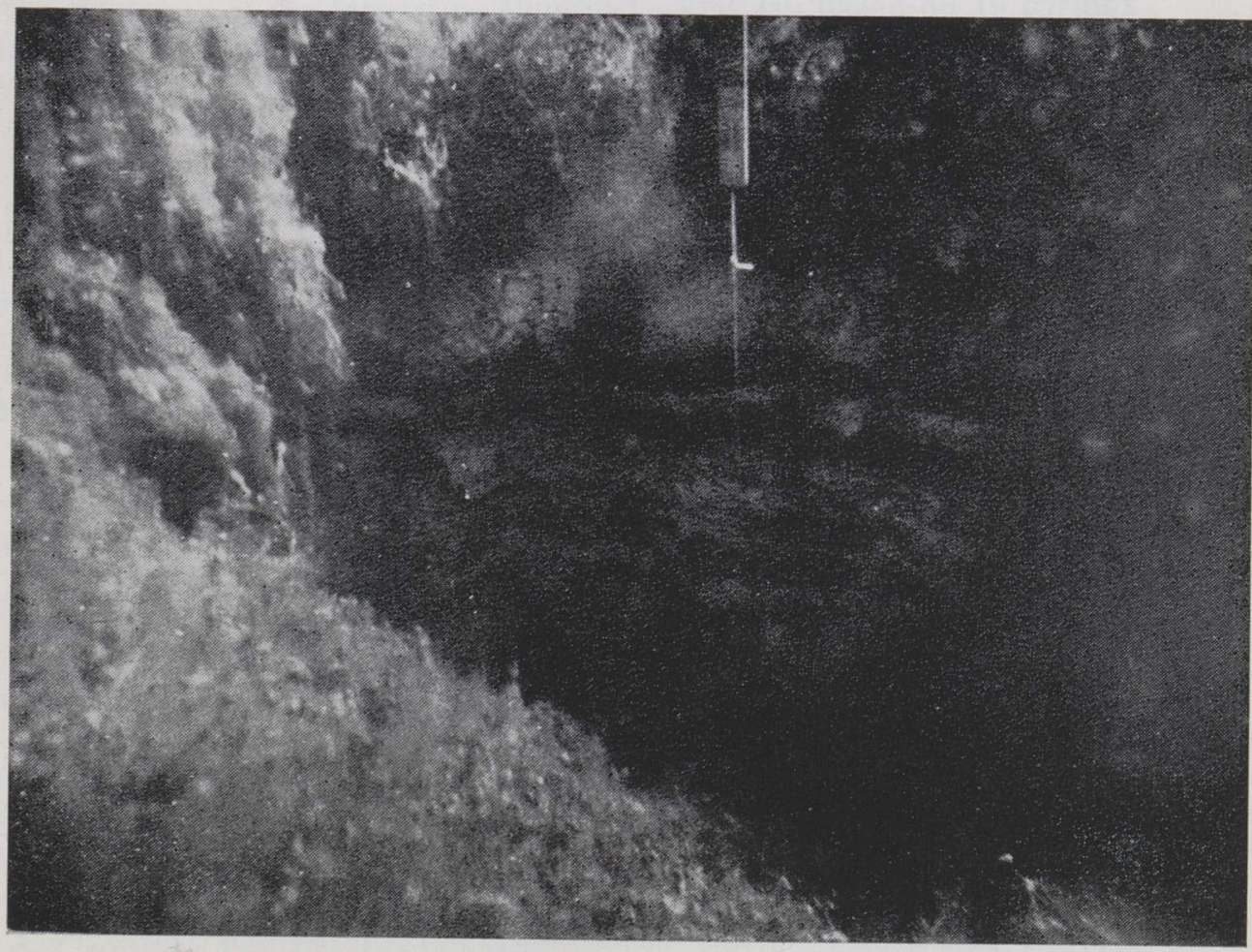

Photo 2. Alternation of sediments in the spring wall of L. Sinijärv. Underwater photo by $H$. Saarse. 

measured with Secchi disc in the horizontal direction at a water depth of $1 \mathrm{~m}$ was $13.5 \mathrm{~m}$, which means that L. Sinijärv has the highest water transparency among the Estonian lakes. In L. Sinijärv there are at least seven springs with different configurations. Their depths are up to $2 \mathrm{~m}$ (Photo 1). The deepest springs are located in the northern and northeastern corners of the lake, close to the shore.

The corings enabled us to establish the maximum thickness of the lacustrine deposits. In the southern part of L. Sinijärv it is 5.1 , in the central part 4.3 , and in the northern part $3.3 \mathrm{~m}$. Layers of lacustrine lime alternating with organic-rich layers are cropping out on the spring walls (Photo 2).

\section{METHODS}

Corings on the Antu group of lakes were carried out from an anchored raft with a Belarus peat sampler. Cores were cut into $2 \mathrm{~cm}$ slices and processed for pollen analyses using standard chemical treatment. The organic fraction was estimated by loss-on-ignition at 500 and $825^{\circ} \mathrm{C}$, the carbonate fraction by measuring the content of carbon dioxide and calculating the total $\mathrm{CaCO}_{3}$. Radiocarbon dates (BP, uncalibrated) were obtained on different organic and carbonate fractions.

\section{SEDIMENT LITHOLOGY}

In 1986 a transect along L. Valgjärv and L. Sinijärv was done (Figs. 2,3 ) and core No. 12 (Fig. 1) was sampled for pollen and radiocarbon analyses. In 1987 peat near L. Linaleo (core 20, Fig. 1) was sampled and analysed for checking the dating.

The thickness of the lacustrine lime in L. Sinijärv based on 19 corings varies between 1.5 and $5.1 \mathrm{~m}$, being on an average $3-4 \mathrm{~m}$. The beige or grey-coloured lime contains subfossil molluscs and fragments of water mosses (Scorpidium). In the sampling point (core 12) the thin fine sand layer $(7.75-7.7 \mathrm{~m})$ is covered with silt containing plant macroremnants $(7.7-7.5 \mathrm{~m})$. The silt is overlaid by a thin gyttja layer $(7.5-7.4 \mathrm{~m})$, laminated lacustrine lime $(7.4-7.05 \mathrm{~m})$, silty lime $(7.05-6.1 \mathrm{~m})$, lime $(6.1-5.6 \mathrm{~m})$, lime with moss fragments and dispersed organic matter $(5.6-4.95 \mathrm{~m})$, pink lime $(4.95-4.35 \mathrm{~m})$, lime with moss fragments (4.35$4.1 \mathrm{~m})$, and grey lime $(4.1-4.0 \mathrm{~m}$, Fig. 4). In L. Valgjärv the basal silt is covered with organic-rich silt, lacustrine lime, gyttja, and the topmost lacustrine lime layer (Fig. 3).

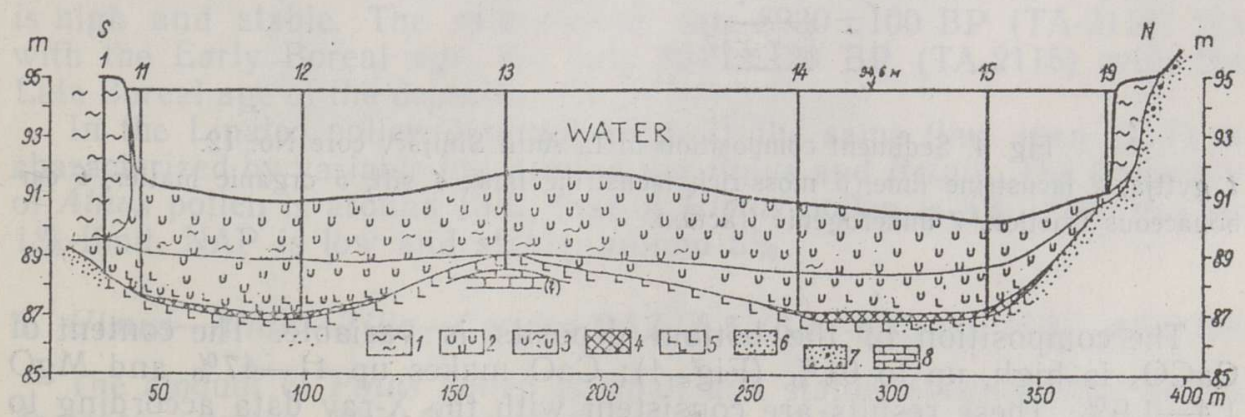

Fig. 2. Transect along L. Antu Sinijärv.

1 peat, 2 lacustrine lime, 3 organic-rich lacustrine lime, 4 gyttja, 5 silt, 6 sand, 7 gravel, 8 limestone. 


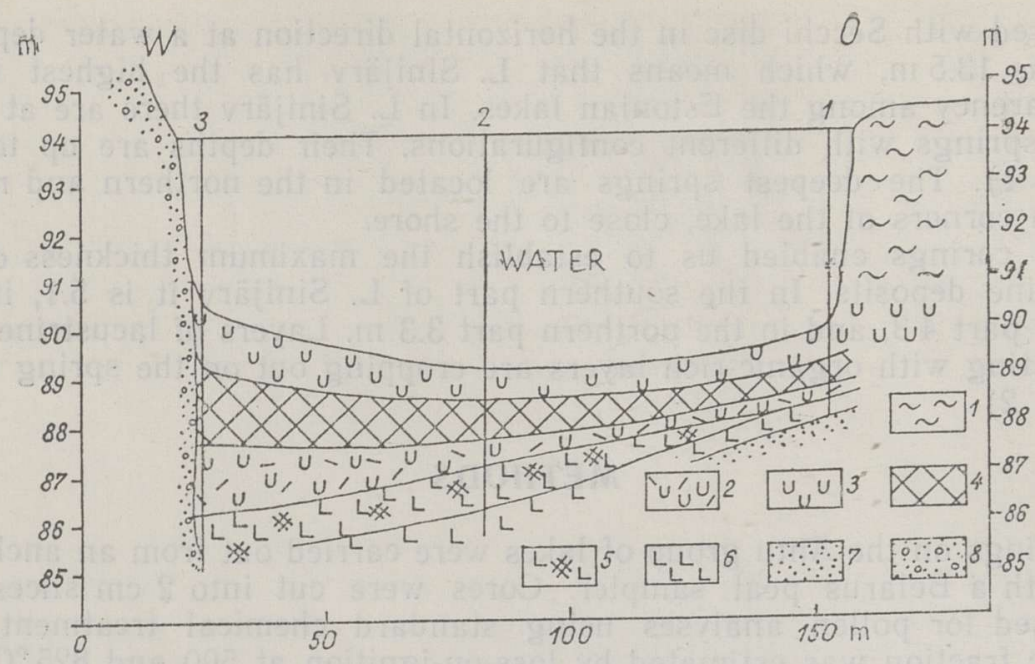

Fig. 3. Transect along L. Antu Valgjärv.

1 peat, 2 peaty lacustrine lime, 3 lacustrine lime, 4 gyttja, 5 silt rich in mosses, 6 silt, 7 sand, 8 gravel.

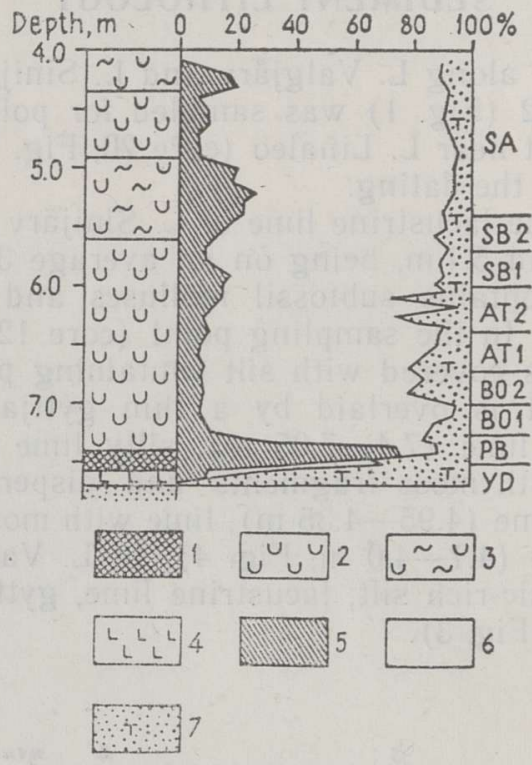

Fig. 4. Sediment composition in L. Antu Sinijärv core No. 12.

1 gyttja, 2 lacustrine lime, 3 moss-rich lacustrine lime, 4 silt, 5 organic matter, 6 carbonaceous fraction, 7 minerogenic fraction.

The composition of the bottom deposits is variable. The content of $\mathrm{CaCO}_{3}$ is high, up to $91 \%$ (Fig. 4); $\mathrm{CaO}$ makes up $41-47 \%$ and $\mathrm{MgO}$ $1.4-1.9 \%$. These results are consistent with the X-ray data according to which the lacustrine lime consists mostly of calcite. The proportion of the organic matter varies between $7-23 \%$, increasing in the gyttja layer up to $74 \%$. The inorganic fraction forms $2-30 \%$ in lime and up to $98 \%$ in silts (Fig. 4). 


\section{BIOSTRATIGRAPHY}

The pollen diagram from core No. 12 (Fig. 5) enabled us to subdivide the 3.75-m-long sediment core into 11 local pollen assemblage zones (PAZ). Their chronology is correlated with the ages of Linaleo mire and L. Raigastvere PAZ (Pirrus et al., 1987; Fig. 6).

\section{NAP-Betula nana-Salix PAZ, $\AA-1$ (7.75-7.5 m), ?-10,000 BP}

The percentage of tree pollen (AP) is low; it increases upwards from 40 to $80 \%$. Pinus and Betula predominate. The frequency of Picea pollen is $1-4 \%$, and it could thus be long-transported. The amount of nonarboreal pollen (NAP) is big $(50-55 \%)$. Among NAP Artemisia is predominant $(34-52 \%)$, it is followed by Chenopodiaceae $(14-28 \%)$, Gramineae $(12-17 \%)$, and Cyperaceae $(7-14 \%)$. Such pollen composition is characteristic of the Younger Dryas. The radiocarbon dating of the plant macroremnants from silt gave the age 10,930 $\pm 200 \mathrm{BP}$ (TA-2119), which is consistent with the beginning of Younger Dryas. The Younger Dryas/Preboreal limit is sharp and marked by the transition of silt to jelly algal gyttja with a low calcareous content $(2 \%)$.

\section{Betula PAZ, $\AA-2(7.5-7.25 \mathrm{~m}), 10,000-9400$ BP}

Betula increases rapidly and dominates (up to $68 \%$ ). Pinus is subdominant (up to $40 \%$ ). The share of AP pollen increases to $95 \%$ and that of NAP decreases to $4-5 \%$. Pinus and Betula curves show contrary trends. Corylus forms $1-2 \%$. Salix and Picea decrease evenly upwards. Ulmus appears in the upper part of the PAZ. Two radiocarbon dates $(11,150 \pm 150 \mathrm{BP}$, TA-2117, and $12,080 \pm 200 \mathrm{BP}, \mathrm{TA}-2118)$ are both erroneous and have been avoided here.

\section{Pinus-Betula PAZ, A-3 (7.25-7.00 m), 9400-9000 BP}

Betula pollen decreases $(60-32 \%)$ and Pinus pollen increases (26$40 \%$ ) together with Ulmus and Corylus. Salix and Picea pollen disappears. The lower limit of the PAZ is marked by the empirical limit of Ulmus and the upper limit by the rational limit of Alnus.

\section{Alnus-Ulmus-Corylus PAZ, А-4 (7.0-6.7 m), 9000-7500 BP}

Betula and Pinus decrease upwards. Alnus increases sharply at the bottom of the PAZ. Corylus and Ulmus curves are rather uniform. Tilia, Quercus, and Picea are sparse. The upper limit of the PAZ is marked by an increase in Ulmus and Tilia and a sharp decrease in Pinus. Total AP is high and stable. The radiocarbon date $8930 \pm 100 \mathrm{BP}$ (TA-2116) fits with the Early Boreal age, the date $8040 \pm 120$ BP (TA-2115) with the Late Boreal age of the deposits.

In the Linaleo pollen diagram (Fig. 7) the same time span (L-1) is characterized by variable but dominating Pinus and Betula. The frequency of Alnus pollen is around $15 \%$, that of Uimus pollen is $5 \%$. Tilia has its $1 \%$-limit. NAP is low and stable, around $5 \%$.

\section{Ulmus-Alnus-Tilia-Corylus PAZ, Ä-5 (6.7-6.35 m), 7500-6600 BP}

The amount of Pinus pollen is small and stable, around $10 \%$. Betula decreases evenly. The Quercetum mixtum (QM) frequency increases. Maxima of Ulmus, Tilia, and Corylus occur. Picea increases abruptly at the end of the PAZ. The upper limit of this PAZ is at the sharp increase in $\mathrm{QM}$ and Picea. 


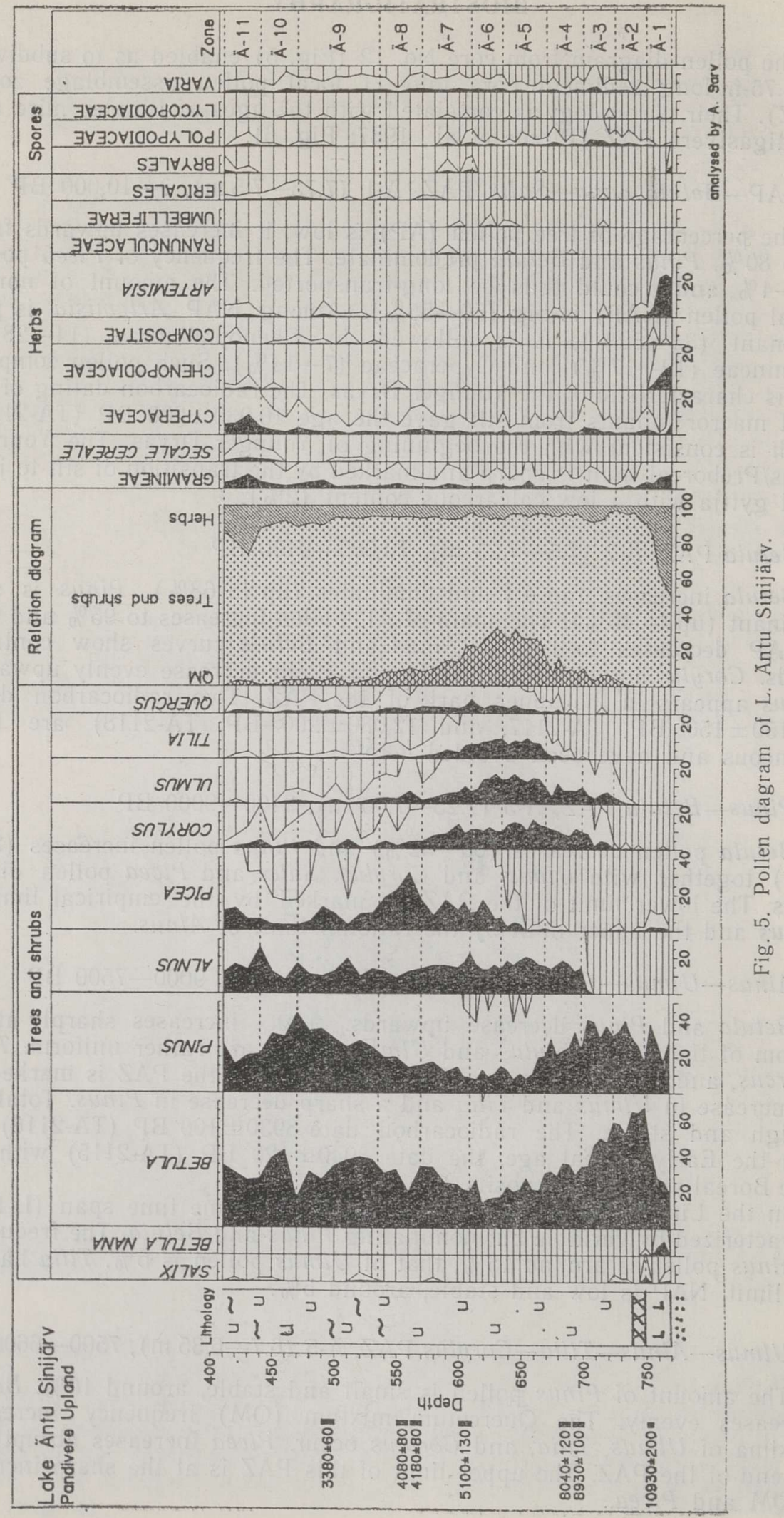


In the Linaleo pollen diagram (Fig. 7, L-2) Betula and Pinus diminish throughout the PAZ. A reverse trend appears in the QM frequency. Alnus and Ulmus have the same values as in the previous PAZ, increasing sharply near the upper limit of the PAZ. The Tilia curve has a remarkable rise. Picea appears, dated to $7430 \pm 80 \mathrm{BP}$, but its pollen frequency is still low $(2-3 \%)$.

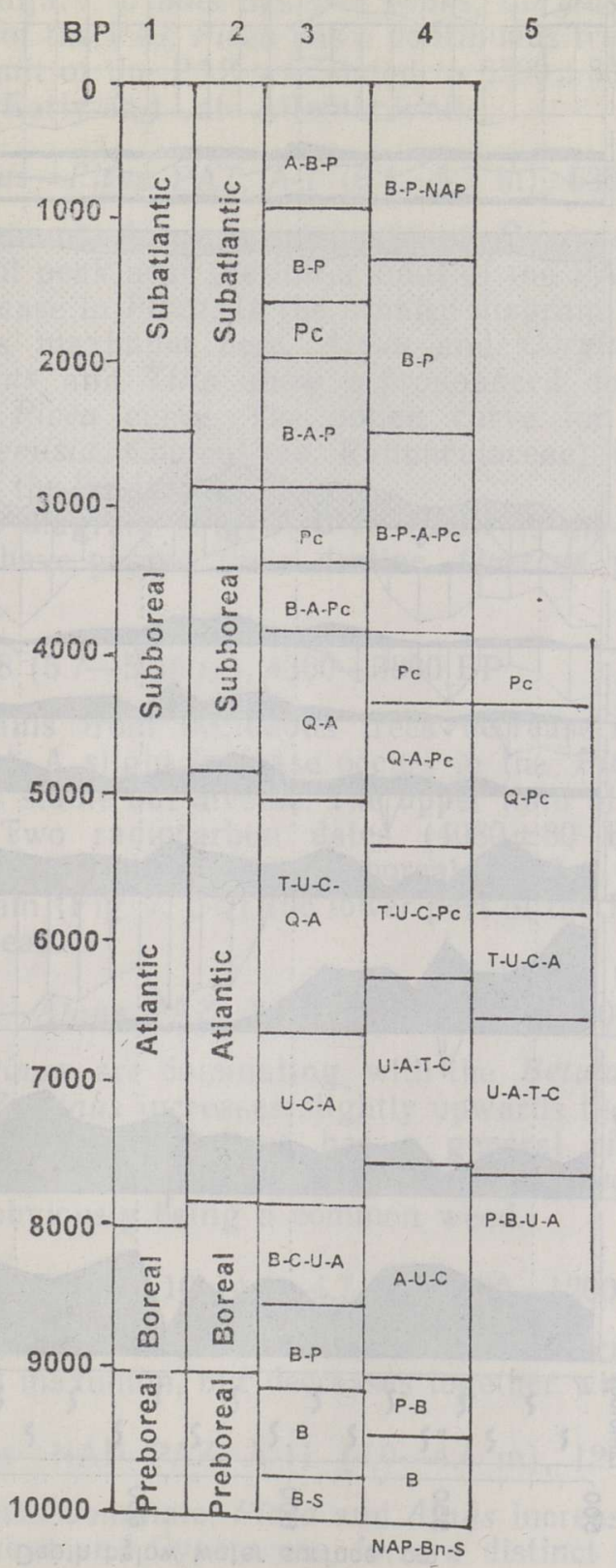

Fig. 6. Correlation of the local pollen assemblage zones from the Nordern (1) (Mangerud et al., 1974) and the Baltic (2) chronozones (Қабайлене \& Раукас, 1993), L. Raigastvere (3), L. Antu Sinijärv (4), and Linaleo mire (5). 


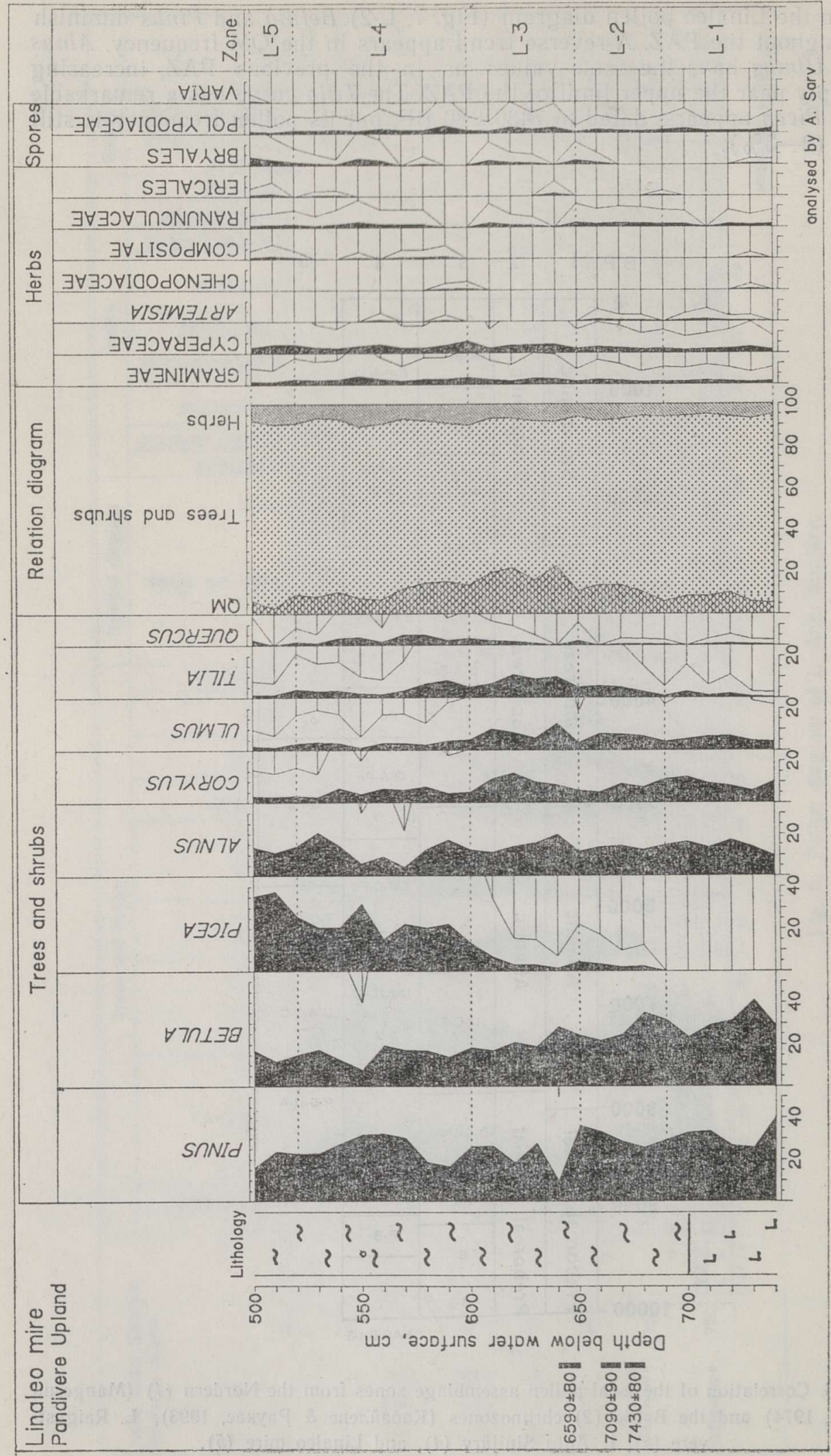


6. Tilia-Ulmus-Corylus-Alnus-Picea PAZ, Ä-6 (6.35-6.1 m), 6600$5300 \mathrm{BP}$

Tilia rises up to $10 \%$ accompanied by high Ulmus and Corylus. There is a culmination in the QM in the lower half of the PAZ. Pinus is low, Betula starts to increase. The upper limit of the PAZ is at the decrease in $\mathrm{QM}$. The radiocarbon date $5100 \pm 130 \mathrm{BP}$ (TA-2114) fits with the Late Atlantic age of the deposits.

In the Linaleo pollen diagram (Fig. 7, L-3) Tilia has the same values as in L. Antu Sinijärv. Ulmus has two peaks, Corylus maximum occurs. Since the middle of the PAZ Picea has a continuous trend toward increasing. The lower limit of the PAZ was dated to $6590 \pm 80 \mathrm{BP}$ (TA-2343). It fits well with the Early and Late Atlantic limit.

\section{Quercus-Alnus-Picea PAZ, A-7 (6.1-5.7 m), 5300-4300 BP}

Betula is dominant, Alnus is subdominant. Quercus is notably high and forms a slight peak near the lower limit of the PAZ. The upper limit is at a sharp increase in Picea. In the Linaleo diagram the Quercus pollen value reaches its maximum here. Alnus and Corylus are moderately represented. Ulmus and Tilia show a pronounced decrease. A reversal trend is in the Picea curve. The pollen curve for terrestrial plants (Cyperaceae, Artemisia, Compositae, Ranunculaceae) increases referring to the openness of the landscape.

In the Linaleo diagram (Fig. 7, L-4) Picea is the most pronounced. Ulmus and Tilia have passed their decline. Quercus pollen has a slight maximum.

\section{Picea PAZ, A-8 (5.7-5.35 m), 4300-3800 BP}

The pollen grains from deciduous trees decrease in favour of Picea, which is dominant. A slight increase occurs in the Pinus curve. Betula decreases. NAP is stable but diverse. The upper limit of the PAZ is at the Picea decrease. Two radiocarbon dates $(4080 \pm 80 \mathrm{BP}, \mathrm{TA}-2112$, and $4180 \pm 80 \mathrm{BP}, \mathrm{TA}-2113$ ) fit with the Subboreal age, but could be older. On the Linaleo diagram (Fig. 7, L-5) the lower part of the PAZ is represented by a clear Picea peak.

\section{Betula-Pinus-Alnus PAZ, A-9 (5.35-4.7 m), 3800-2400 BP}

Betula and Pinus are dominating, with the Betula maximum in the middle of the PAZ. Pinus increases slightly upwards the PAZ limit. Picea forms the second peak. NAP curve has a general rise and increased diversity since the second half of the PAZ. Secale cereale appears at the end of the PAZ, obviously being a common weed.

\section{Betula-Pinus PAZ, A-10 (4.4-4.7 m), 2400-1200 BP}

Betula is dominant, Pinus is subdominant and decreases. Picea does not form a second maximum, but decreases together with Alnus.

\section{Betula-Pinus-NAP PAZ, Ā-11 (4.0-4.4 m), 1200-0 BP}

Betula and Pinus dominate, Picea and Alnus increase. Nemoral herbs, especially Gramineae and Cyperaceae, form a distinct peak. 


\section{COMPARISON OF POLLEN DIAGRAMS}

A comparison of the L. Sinijärv pollen diagram with the pollen diagrams from the Linaleo mire and L. Raigastvere (Pirrus et al., 1987) reveals several similar patterns and allows a correlation of their PAZ (Fig. 6). The Early Holocene pollen assemblages are dominated by Betula. Unlike at Raigastvere the Pinus frequency is high in the Antu area in the Boreal. Alnus immigrated about $9000 \mathrm{BP}$, simultaneously to Vooremaa and Pandivere. The order of the immigration of the deciduous trees (UlmusCorylus-Alnus-Tilia-Quercus) was similar at Antu and Raigastvere. The concentration of $Q M$ pollen is quite high throughout the Atlantic period. A slight maximum of Quercus pollen occurs at the Atlantic/Subboreal transition. The most remarkable difference between the two diagrams is that at Antu Picea forms only one pronounced peak in the Late Subboreal, whereas at Raigastvere it forms three peaks (Pirrus et al., 1987).

\section{RADIOCARBON DATES}

Radiocarbon dates from L. Sinijärv, L. Valgjärv, and the Linaleo mire are presented in the Table.

Radiocarbon dates (BP, uncalibrated)

Lab. No.

Depth, m

Date

Material

L. Sinijärv (dated by A. Liiva)

$\begin{array}{llll}\text { TA-2111 } & 4.9-5.0 & 3380 \pm 60 & \text { Lacustrine lime (carbon. fr.) } \\ \text { TA-2112 } & 5.5-5.6 & 4080 \pm 80 & \text { Lacustrine lime (carbon. fr.) } \\ \text { TA-2113 } & 5.6-5.7 & 4180 \pm 80 & \text { Lacustrine lime (carbon. fr.) } \\ \text { TA-2114 } & 6.0-6.1 & 5100 \pm 130 & \text { Lacustrine lime (carbon. fr.) } \\ \text { TA-2115 } & 6.8-6.9 & 8040 \pm 120 & \text { Lacustrine lime (carbon. fr.) } \\ \text { TA-2116 } & 6.9-7.0 & 8930 \pm 100 & \text { Lacustrine lime (carbon. fr.) } \\ \text { TA-2117 } & 7.3-7.4 & 11150 \pm 150 & \text { Lacustrine lime (carbon. fr.) } \\ \text { TA-2118 } & 7.4-7.5 & 12080 \pm 200 & \text { Gyttja (organic fr.) } \\ \text { TA-2119 } & 7.5-7.6 & 10930 \pm 200 & \text { Plant remnants (organic fr.) }\end{array}$

L. Valgjärv (dated by R. Rajamäe)

$\begin{array}{lll}\text { Tln-1701 } & 6.1-6.2 & 3170 \pm 40 \\ \text { Tln-1713 } & 6.2-6.3 & 4170 \pm 70 \\ \text { Tln-1714 } & 6.2-6.3 & 4430 \pm 65\end{array}$

Peaty gyttja (organic fr.)

Peaty gyttja (carbon. fr.)

Peaty gyttja (organic fr.)

Linaleo mire (dated by A. Liiva)

$\begin{array}{llll}\text { TA-2343 } & 6.4-6.5 & 6590 \pm 80 & \text { Peat (organic fr.) } \\ \text { TA-2344 } & 6.6-6.7 & 7090 \pm 90 & \text { Peat (organic fr.) } \\ \text { TA-2345 } & 6.7-6.8 & 7430 \pm 80 & \text { Peat (organic fr.) } \\ \text { TA-2346 } & 6.7-6.8 & 9060 \pm 90 & \text { Carbonate fr. }\end{array}$


The bottom deposits of all the lakes in the Antu group may be contaminated with old carbonate due to the calcareous tills and carbonate bedrock on the catchment and the feeding of lakes with carbonate-rich ground water. In spite of that most of the radiocarbon dates fit well with the chronozone ages and the vegetational events in the area (Fig. 6). The date $5100 \pm 130 \mathrm{BP}$ (TA-2114) marks the Subboreal/Atlantic limit and fits with the traditional limit age (c. $5000 \mathrm{BP})$. We dated the limit of the Early and Late Atlantic periods in the Linaleo mire at $6590 \pm 80$ (TA-2343); according to the Estonian stratigraphic scale it is 6600 (Кабайлене \& Paукас, 1993). Only some PAZ limits are shifted towards older ages in comparison with the Raigastvere PAZ ages (Fig. 6).

We also compared several vegetational events in the Antu region with those of L. Raigastvere. The Betula maximum in L. Raigastvere is dated at 9200 , Alnus expansion at 8400 , Corylus peak before its decline at 5000 , the first peak of Picea at 3800, and the peak of Alnus at 800 BP. The radiocarbon dates of the same events from L. Sinijärv show sometimes older ages, sometimes younger ones. So, the apparent age of L. Sinijärv samples varies. This means that beside the old carbon there are obviously other factors that affect the radiocarbon cates of calcareous deposits. We should also keep in mind that the vegetational events and PAZ limits are time transgressive and are not the best instrument for measuring the validity of the radiocarbon dates.

\section{OUTLINES ON THE VEGETATION HISTORY}

There are more than 20 pollen diagrams from the Pandivere Upland (Antu, Järvasoo, Avanduse, Savalduma, Lusiku, Tapa, Loobu, Haljala, etc.; Veber, 1961; Männil, 1961, 1964; Männil \& Pirrus, 1963). They provide information on the vegetational history of different parts of the upland.

The surroundings of Antu were densely forested during the Late Boreal and the Atlantic periods. The first deforestation caused by Neolithic clearance started on the transition of AT/SB, marked about $5000 \mathrm{BP}$ by a contemporaneous Uimus and Tilia decline, an increase in NAP, and a decrease in AP. The second deforestation phase occurred in the middle of the Early Subatlantic (Fig. 5, A-9), when NAP pollen, especially Gramineae, increased (Fig. 5). Betula and Alnus diminished, Picea increased, indicating the landscape openness. The third phase of rather clearly expressed human impact covers the last 1100 years BP. This phase saw also the beginning of Secale cereale cultivation. It was followed by a new forest regeneration during the last 50 years.

\section{HYDROLOGICAL EVENTS}

On the basis of the sediment lithology and deposition rate and the mollusc succession (Männil, 1961, 1964) it may be concluded that at the beginning of the Preboreal the lake level was high and algal gyttja accumulated. The lake level started to decrease in the Late Boreal. It was high in the Atlantic and low during the Subboreal, when on L. Sinijärv cape Hypnum peat accumulated (R. Pirrus, pers. comm.). The peat was underlaid and covered with lacustrine lime. Almost at the same time (4100 -3200 BP) lacustrine lime with water mosses deposited in the deepest part of L. Sinijärv and peaty gyttja in L. Valgjärv. The lake level has been high since the mid-Subatlantic. As the lakes are fed by bottom springs, the water-level fluctuation reflects, first of all, changes in the ground-water table and, indirectly, changes in the precipitation-evaporation ratio. 


\section{ARCHAEOLOGICAL EVENTS}

During the Pre-Roman Iron Age (2500-1950 BP) the climate deteriorated, becoming more continental and drier. This led to a decrease in land cultivation (Jaanits et al., 1982). On L. Sinijärv diagram the change in land use is reflected as a decrease in NAP and an increase in AP pollen (Fig. 5, first part of $\AA-10 \mathrm{PAZ}$ ), showing that the landscape became more closed. In the Roman Iron Age, after $1800 \mathrm{BP}$, land cultivation diminished. In the Middle Iron Age (1600-1200 BP) the population density and the yields of crops increased rapidly. At that time the Antu Punamägi stronghold was erected $5 \mathrm{~km}$ south from the Antu group of lakes and it was still in use during the Late Iron Age (1200-800 BP, Jaanits et al., 1982). Agriculture made a noticeable progress. Rye, barley, wheat, oats, and flax were cultivated. This period corresponds to the uppermost herb peak, AP regression, and Secale cereale maximum (Fig. 5, A-11 PAZ). These events are also traced on the pollen diagram compiled by R. Pirrus from the cape of Antu Sinijärv (unpublished data).

\section{GEOLOGICAL HISTORY OF THE ÄNTU GROUP OF LAKES}

After the recession of the ice from the Pandivere Upland L. Pandivere $(\mathrm{Pa})$, a local ice marginal lake with levels PaI $128 \mathrm{~m}$, PaIII $110 \mathrm{~m}$, PaIV 90 m, was formed (Раукас et al., 1971). This large lake split up, leaving behind remnants that existed there up to the Early Holocene. The three northern Antu lakes were also such residual lakes. They separated from one another either in the Boreal during the low water level or in the Atlantic when the area started to paludify. Since then all these three Antu lakes have developed as isolated alkaline lakes unique in Estonia.

\section{CONCLUSIONS}

1. The Pandivere Upland was proposed as one palaeoecological type region (Saarse \& Raukas, 1984). Its modern climate is continental, soils are fertile, and the degree of land cultivation is high. L. Raigastvere was selected as a reference site and therefore L. Antu Sinijärv can serve as a secondary reference site clearing up the sedimentational peculiarities, differences in radiocarbon dates, and the vegetational and geological history of the alkalitrophic lakes of the Pandivere Upland.

2. The lakes of the Äntu group differ in the accumulation of the highly calcareous lime since the middle of the Preboreal onwards. At the beginning of the Preboreal L. Sinijärv passed the oligotrophic phase and jelly algal gyttja accumulated. The Early and Late Subatlantic deposits contain greater amounts of the organic fraction while the carbonate fraction has decreased. This can indicate to changes in the trophic stage and/or water transparency as well as lake level.

3. The L. Antu Sinijärv pollen diagram is similar to that of L. Raigastvere, with the following differences. The Betula pollen frequency is high only in the Preboreal, not continuing in the Boreal as is the case in Vooremaa. Ulmus immigrated to the study area at the end of the Preboreal, followed by Corylus at the beginning of the Boreal, Alnus in the Late Boreal, Tilia and Quercus at the transition of the Boreal/Atlantic, and Picea in the Atlantic. The anthropogenic indicators are rather poor with a remarkable cultural influence traced since 1100 BP.

4. Radiocarbon dates performed from the calcareous fraction have commonly some apparent age complicate to measure. Most of the radio- 
carbon dates fit well with the pollen stratigraphy and vegetational events from L. Raigastvere.

5. The lake level was considerably high at the beginning of the Preboreal, during the Atlantic, and since the middle of the Subatlantic. It was at its lowest between 4100 and $3200 \mathrm{BP}$, which coincides with the conclusions made earlier (Saarse \& Harrison, 1992).

6. After the ice recession all the three northern Antu lakes formed one large lake, whose remnants existed here up to the Atlantic (Boreal?), when the area started to paludify and the lakes separated from one another.

\section{ACKNOWLEDGEMENTS}

The authors are grateful to A. Raukas, R. Vaikmäe, and A. Miidel for critical remarks. H. Saarse and A. Rähni took part in the lake sediment corings in the field. Pollen analyses were provided by A. Sarv, radiocarbon dates from L. Valgjärv by R. Rajamäe, chemical analyses were made by L. Säga, X-ray diffractograms by K. Utsal. H. Kukk revised our English and P. Pärkma made drawings. We express our thanks to all these people.

\section{REFERENCES}

Jaanits, L., Laul, S., Lõugas, V., Tõnisson, E. 1982. Eesti esiajalugu. Eesti Raamat, Tallinn.

Mäemets, A., Saarse, L. 1995. Väikejärved. - In: Raukas, A. (ed.). Eesti Loodus. Valgus, Tallinn, $198-223$.

Mangerud, J., Andersen, S. T., Berglund, B. E. and Donner, J. 1974. Quaternary stratigraphy of Norden, a proposal for terminology and classification. - Boreas, 3, $109-126$.

Männil, R. 1961. Pandivere kõrgustiku piirkonnas esinevatest holotseensetest järvesetetest. - ENSV TA Geol. Inst. Uurimused VII. Antropogeeni geoloogia. Tallinn, $115-133$.

Männil, R. 1964. Järvelubja lasundite levik ja stratigraafia Eestis. Cand. Sc. thesis. Eesti Teaduste Akadeemia Keskarhiiv. Tallinn.

Männil, R., Pirrus, R. 1963. Hilisglatsiaalsed setted Haljala ja Võru läbilõikes. Eesti NSV TA Geol. Inst. Uurimused XII. Tallinn, 95-106.

Pirrus, R., Rõuk, A.-M., Liiva, A. 1987. Geology and stratigraphy of the reference site Lake Raigastvere in Saadjärv drumlin fields. - In: Raukas, A. and Saarse, L. (eds.). Palaeohydrology of the temperate zone II. Lakes. Tallinn, 101-122.

Saarse, L. and Harrison, S. 1992. Holocene lake-level changes in the eastern Baltic region. - In: Estonia, Man and Nature. Tallinn, 6-20.

Saarse, L. and Raukas, A. 1984. Background to a multidisciplinary investigation of mires, lakes and rivers. - In: Punning, J.-M. (ed.). Estonia. Nature, Man, Economy. Tallinn, 78-87.

Veber, K. 1961. Soo- ja järvesetete stratigraafiast Pandivere kõrgustikul. ENSV TA Geol. Inst. Uurimused VII. Antropogeeni Geoloogia. Tallinn, 115-133.

Кабайлене М. В., Раукас А. В. 1993. Стратиграфия и история позднеледниковья и голоцена Прибалтики. - Науч. тр. вузов Литвы. Геол., 14, 167-178.

Раукас А., Ряхни Э., Мийдел А. 1971. Краевые ледниковые образования Северной Эстонии. Валгус, Таллинн. 


\section{ÄNTU JÄRVEDE GEOLOOGIA}

\section{Leili SAARSE, Arvi LIIVA}

On toodud andmed Antu Sini-, Vahe- ja Valgjärve morfomeetria, põhjasetete koostise ja kujunemise kohta. On võrreldud Sinijärve ja Raigastvere järve ning Linaleo soo õietolmu tsoone ja nende vanuseid radiosüsiniku dateeringute põhjal. On järeldatud, et õietolmu tsoonid ei oma märkimisväärset «vananemise» tendentsi, nagu võiks oletada. Antu Sinijärv on unikaalne oma erakordselt selge vee ja läbi Holotseeni kestva karbonaatsete setete kuhjumise tõttu. Antu Sinijärv on praegu ainuke Pandivere kõrgustiku järv, mille põhjasetteid on uuritud samaaegselt lito-, bio- ja kronostratigraafiliste meetoditega, ja seda võiks kasutada Raigastvere kõrval kui sekundaarset võtmejärve.

\section{ГЕОЛОГИЯ ГРУППЫ ОЗЕР В ЭНТУ}

\section{Лейли СААРСЕ, Арви ЛИЙВА}

Приведены морфометрические показатели трех озер в Энту Синиярв, Вахеярв и Валгъярв, а также данные об истории их развития и условиях формирования, литологии донных отложений и основных этапах развития растительности. Сравнение спорово-пыльцевых диаграмм и радиоуглеродных датировок озер Синиярв и Райгаствере, а также болота Линалео показало, что их озерные отложения не проявляют заметной тенденции $\mathrm{k}$ «старению». Вода в оз. Синиярв, накопителе карбонатных отложений, уникальна по своей прозрачности. Әто единственное на Пандивереской возвышенности озеро, донные отложения которого изучены комплексно - лито-, био- и хроностратиграфическими методами. 